Arq. Bras. Med. Vet. Zootec., v.67, n.3, p.927-934, 2015

\title{
Milk fatty acid profile from grazing buffaloes fed a blend of soybean and linseed oils
}

\author{
[Perfil de ácidos graxos do leite de búfalas a pasto recebendo uma mistura de \\ óleo de soja e linhaça na dieta] \\ G.A. Gagliostro ${ }^{1}$, E.M. Patiño ${ }^{2}$, M. Sanchez Negrette ${ }^{2}$, G. Sager ${ }^{2}$, L. Castelli $^{3}$, L.E. Antonacci ${ }^{1}$, \\ F. Raco ${ }^{3}$, L. Gallello ${ }^{3}$, M.A. Rodríguez ${ }^{3}$, C. Cañameras ${ }^{3}$, M.L. Zampatti ${ }^{3}$, C. Bernal ${ }^{4}$ \\ ${ }^{1}$ Instituto Nacional de Tecnología Agropecuaria (INTA) - Estación Experimental Balcarce, Ar \\ ${ }^{2}$ Facultad de Ciencias Veterinarias - Universidad Nacional del Nordeste (UNNE) - Corrientes, Ar \\ ${ }^{3}$ INTI-Lácteos - Parque Tecnológico Miguelete - San Martín - Buenos Aires, Ar \\ ${ }^{4}$ Facultad de Bioquímica y Ciencias Biológicas - Universidad Nacional del Litoral (UNL) - Santa Fe, Ar
}

\begin{abstract}
The aim of the study was to examine the changes in milk fatty acid (FA) profile of grazing buffaloes fed either low $(\mathrm{L}, 276 \mathrm{~g} / \mathrm{d})$ or high $(\mathrm{H}, 572 \mathrm{~g} / \mathrm{d})$ doses of a blend $(70: 30$, wt/wt) of soybean and linseed oils. Fourteen multiparous Mediterranean buffaloes grazing on a native pasture were fed $4 \mathrm{~kg} / \mathrm{day}$ of a commercial concentrate containing no supplemental oil over a pre-experimental period of ten days. The baseline milk production and composition and $\mathrm{milk}$ FA profile were measured over the last three days. After this pre-experimental period the animals received the same concentrate added with either the $\mathrm{L}$ or $\mathrm{H}$ oil doses for 26 additional days. Milk yield (g/animal/day) did not differ at the start (1776 \pm 522 and $1662 \pm$ 291 for $\mathrm{L}$ and $\mathrm{H}$, respectively, $\mathrm{P}<0.622)$ or at the end of the trial $(4590 \pm 991$ and $4847 \pm 447$ in $\mathrm{L}$ and $\mathrm{H}$, respectively, $\mathrm{P}<0.543)$. Baseline milk fat content $(\mathrm{g} / \mathrm{kg})$ averaged $77.1( \pm 20.5)$ in $\mathrm{L}$ and $74.3( \pm 9.9)$ in $\mathrm{H}$ $(\mathrm{P}<0.10)$ and was reduced $(\mathrm{P}<0.031)$ to $60.7( \pm 23.6)$ and $49.4( \pm 11.2)(\mathrm{P}<0.0031)$ respectively after $\mathrm{L}$ and $\mathrm{H}$ with no differences between treatments $(\mathrm{P}<0.277)$. Baseline milk protein content $(\mathrm{L}=43.2 \pm 3.4$ and $\mathrm{H}=$ $44.3 \pm 6.9 \mathrm{~g} / \mathrm{kg})$ increased after oil supplementation $(\mathrm{P}<0.0001)$ in both $\mathrm{L}(73.2 \pm 6.0 \mathrm{~g} / \mathrm{kg})$ and $\mathrm{H}(68.4 \pm$ $4.9 \mathrm{~g} / \mathrm{kg}$ ) without differences between oil doses $(\mathrm{P}<0.123)$. Milk fat content of 14:0 decreased after oil supplementation only in the $\mathrm{H}$ treatment $(5.29$ to $4.03, \mathrm{P}<0.007)$ whereas that of 16:0 was reduced $(\mathrm{P}<0.001)$ at both $\mathrm{L}(24.49$ to $19.75 \mathrm{~g} / 100 \mathrm{~g} \mathrm{FA})$ and $\mathrm{H}(25.92$ to $19.17 \mathrm{~g} / 100 \mathrm{~g}$ FA) doses. The reduction of total content of $12: 0$ to $16: 0$ was higher $(\mathrm{P}<0.052)$ in $\mathrm{H}(32.02$ to $23.93 \mathrm{~g} / 100 \mathrm{~g} F A)$ than $\mathrm{L}(30.17$ to $25.45 \mathrm{~g} / 100 \mathrm{~g} F A)$. Vaccenic acid content increased $(\mathrm{P}<0.001)$ from 5.70 to $13.24 \mathrm{~g} / 100 \mathrm{~g} \mathrm{FA}$ in $\mathrm{L}$ and from 5.25 to 16.77 in $\mathrm{H}$, with higher results in the in $\mathrm{H}$ treatment $(\mathrm{P}<0.001)$. Baseline rumenic acid was sharply increased $(\mathrm{P}<0.001)$ in $\mathrm{L}(1.80$ to $4.09 \mathrm{~g} / 100 \mathrm{~g} \mathrm{FA},+127 \%)$ and $\mathrm{H}(1.60$ to $4.61 \mathrm{~g} / 100 \mathrm{~g} \mathrm{FA},+187 \%)$ with no differences between $\mathrm{L}$ and $\mathrm{H}(\mathrm{P}<0.19)$. Overall, these results indicate a pronounced improvement in the nutritional value of milk fat from grazing buffaloes fed little amounts $(0.276 \mathrm{~g} /$ day) of a blend of soybean and linseed oils.
\end{abstract}

Keywords: buffaloes, conjugated linoleic acid, lactation, soybean oil, linseed oil

\section{RESUMO}

O objetivo do presente estudo foi avaliar as mudanças no perfil de ácidos graxos do leite de búfalas leiteiras recebendo baixas $(B, 276 \mathrm{~g} / \mathrm{d})$ ou altas $(A, 572 \mathrm{~g} / \mathrm{d})$ doses de uma mistura de óleos de soja e linhaça (70:30, peso/peso) na dieta. Quatorze búfalas multíparas da raça Mediterrânea, mantidas em pastagens nativas, receberam $4 \mathrm{~kg} /$ dia de um concentrado comercial sem adição de óleo (pré-tratamento) ao longo de um período pré-experimental de 10 dias. A produção de leite individual e amostras de leite foram coletadas individualmente para determinação dos valores basais de composição e perfil de ácidos graxos do leite nos últimos três dias. Após este período, os animais receberam o mesmo concentrado adicionado de B ou A por 26 dias. A produção de leite (g/animal/dia) não diferiu no início $(1776 \pm 522$ e $1662 \pm 291$ para $B$ e A, respectivamente $(P<0,622)$ e no final do período experimental $(4590 \pm 991$ e $4847 \pm 447$ para $L$ e $H$, respectivamente, $P<0,543)$. O teor de gordura do leite $(\mathrm{g} / \mathrm{lo0g})$ apresentou valores médios de $77,1( \pm 20,5)$ para $B$ e 74,3 $( \pm 9,9)$ para $A(P<0,10)$ durante o período pré-tratamento, mas foi reduzido $(P<0,03)$ após o

Recebido em 3 de julho de 2014

Aceito em 20 de outubro de 2014

E-mail: gagliostro.gerardo@inta.gob.ar 
fornecimento das dietas com óleo para $60,7 \quad( \pm 23,6)$ e 49,4 ( $\pm 11,2)$, respectivamente para $B$ e A, não havendo diferenças entre tratamentos $(P<0,277)$. Os teores basais de proteína do leite $(B=43,2 \pm 3,4 e$ $A=44,3 \pm 6,9 \mathrm{~g} / \mathrm{kg})$ aumentaram após a suplementação com óleo $(P<0,0001)$ em ambos $B(73,2 \pm 6,0 \mathrm{~g} / \mathrm{kg})$ e A $(68,4 \pm 4,9 \mathrm{~g} / \mathrm{kg})$, não ocorrendo diferenças entre tratamentos $(P<0,123)$. O teor médio basal de 14:0 na gordura do leite $(4,76 \mathrm{~g} / 100 \mathrm{~g} A G)$ foi reduzido após a suplementação da dieta com óleo somente no tratamento A (5,29 para 4,03, $P<0,007)$. O teor de 16:0 na gordura do leite foi reduzido $(P<0,001)$ nos tratamentos $B$ (24,49 para 19,75g/100g $A G)$ e A (25,92 para 19,17g/100g AG). A redução nos teores de 12:0+14:0+16:0 na gordura do leite foi maior $(P<0,052)$ em $A(32,02$ para $23,93 \mathrm{~g} / 100 \mathrm{~g} A G)$ do que em $B(30,17$ para $25,45 \mathrm{~g} / 100 \mathrm{~g} A G)$. O teor de ácido vacênico $(A V)$ na gordura do leite aumentou $(P<0,001)$ de 5,70 para $13,24 \mathrm{~g} / 100 \mathrm{~g}$ AG em $B$ e de 5,25 para 16,77 em A, resultando em maior teor de AV neste último $(P<0,001)$. $O$ teor basal de ácido rumênico aumentou expressivamente $(P<0,001)$ em B $(1,80$ para 4,09g/100g AG, $+127 \%)$ e A (1,60 para 4,61g/100g AG, $+187 \%)$, não havendo diferenças entre tratamentos $(P<0,19)$. No geral, estes resultados indicam uma melhora pronunciada no valor nutricional da gordura do leite de búfalas a pasto recebendo pequenas quantidades $(0,276 \mathrm{~g} / \mathrm{dia})$ de uma mistura de óleos de soja e linhaça na dieta.

Palavras-chave: búfalos, ácido linoleico conjugado, lactação, óleo de soja, óleo de linhaça

\section{INTRODUCTION}

Buffalo milk is a rich source of nutrients with higher levels of total protein, medium chain FA, conjugated linoleic acid (CLA) and contents of retinol and tocopherols than those of cow milk (Ahmad et al., 2013). Higher amounts of saturated fatty acids (SFA) and lower amounts of unsaturated fatty acids (UFA) were also reported in buffalo $\mathrm{milk}$ compared to cow milk together with higher contents of myristic (14:0) and palmitic (16:0) FA (Ménard et al., 2010). These FA (14:0 and 16:0) are classed as atherogenic (Ulbritch and Southgate, 1991) if consumed in excess and associated to increased risk of heart disease (Stanton el al., 2003; Chilliard and Ferlay, 2004). The supplementation with polyunsaturated rich oils may decrease the concentration of the potentially atherogenic FA in cows (Rego et al., 2005) and in lactating buffaloes (Oliveira et al., 2009). Concerning the potential functional benefits of milk, a current special interest exists on conjugated linoleic acid (CLA) concentration, because it plays an important role in regulating plasma lipid concentrations and cardiovascular functions, reducing cancer incidence, as well as blocking tumor growth and metastasis from cancer breasts (Parodi, 1999). Between the natural CLA isomers, the cis- 9 trans-11 18:2 or rumenic acid (RA) is the most present $(80-90 \%)$ in milk fat. Vaccenic acid (VA, trans-11 18:1) is the main natural trans FA and precursor of RA in the mammary gland and other tissues. It may also have anticarcinogenic properties and can be metabolized by humans to RA (Stanton et al.,
2003). Buffalo milk contains higher amounts of RA and VA than cow milk (Ahmad et al., 2013; Ménard et al., 2010).). Milk fat is considered the main natural source of RA and its concentration in milk is highly dependent on the type of diet and lipid supplementation in dairy cows (Chilliard et al., 2007) and buffaloes (Fernandes et al., 2007; Patiño et al., 2010, Oliveira et al. 2009). To our knowledge the information about the effect of providing a combination of soy and linseed oils on the full milk FA profile of grazing buffaloes is non-existent. The aim of this experiment is to evaluate the effect of supplementation with a blend (70:30 wt/wt) of soybean and linseed oils on the chemical composition of milk and the FA profile in lactating buffaloes in natural grassland.

\section{MATERIALS AND METHODS}

The experiment was conducted during the months of October - November 2013 at the commercial farm of Nuestra Señora de Itatí (Route 12, Km 1098, Itatí Department, site Yacareí Province of Corrientes, Argentina) with an 80 hectares field and natural grassland. Fourteen multiparous Mediterranean buffaloes (milked after two years of inactivity) between the second and the third part of their lactation were used (7 with $\mathrm{L}$ and 7 with $\mathrm{H}$ doses). Experimental procedures and buffalo management were performed according to the recommendations of good management practices (GMP) of the National Sanitarian Service (SENASA, Argentina). As the experiment progressed animals were gradually adapted to the milking routine and oxytocin was used to 
facilitate milk release resulting in a gradual increase in daily milk production as the experiment wore on. Animals grazed a native pasture composed by Andropogon lateralis $(\mathrm{NDF}=64.5 \% ; \quad \mathrm{ADF}=39.1 \%, \quad$ lignin $=5.1 \%$ and $\mathrm{CP}=6.4 \%)$, Schyzachirium paniculatum $(\mathrm{CP}=4-$ $10 \%)$ and Paspalum notatum ( $\mathrm{NDF}=59.2 \%$, $\mathrm{ADF}=35.4 \%$, Lignin $=3.5 \%$ and $\mathrm{CP}=8.5 \%$ ). They were supplemented with $4 \mathrm{~kg} / \mathrm{day}$ of a commercial concentrate $(87.95 \%$ DM; $4.21 \%$ EE, $14.52 \% \mathrm{CP}, 65.57 \% \mathrm{NDF}, 11.03 \%$ ADF, 89.00\% TDN and ED 3.97 Mcal DE/kg DM) composed (DM basis) by cracked corn grain $(50 \%)$, rice bran $(10 \%)$, pelleted sunflower $(10 \%)$, soybean $(5 \%)$ and wheat meals, bovine fat $(11 \%)$ and a mineral premix (4\%). Ten days prior to the start of the experiment the animals consumed pasture $(63 \%)$ plus concentrate $(27 \%)$ without oil to determine the baseline (B) milk composition and FA profile on samples taken over the last three days. After this period the animals were supplemented with a blend (70:30, $\mathrm{wt} / \mathrm{wt}$ ) of soybean and linseed oils at a low (L, $276 \mathrm{~g} / \mathrm{d})$ and a high $(\mathrm{H}, 572 \mathrm{~g} / \mathrm{d})$ doses mixed to the concentrate. Oil represented about 2.21 and $4.42 \%$ of total DM intake if a maximum DM intake of $12.5 \mathrm{~kg} / \mathrm{animal} / \mathrm{day}$ is assumed (Kathirvelan and Tyagi, 2009). Oils were manually mixed to the concentrate and thoroughly consumed during milking time in the morning. After milking animals were left in the grazing paddock until the next day.

Animals were milked mechanically once a day at 8am and individual samples $(100 \mathrm{ml})$ were collected. An aliquot of $10 \mathrm{~mL}$ was used for chemical analysis while the remaining $90 \mathrm{~mL}$ were immediately frozen $(-20)$ until FA determination by GLC. Before the start of oil supply milk yield was individually recorded and milk samples were obtained during three consecutive days to measure the $\mathrm{B}$ milk composition and FA profile. The procedure was repeated over the last 3 days of the experimental period. Milk samples were analyzed for fat, protein and nonfat solids by infrared spectrophotometry (Milk analyzing device Model: Master Eco). The calibration routine is done with reference to a standard pattern using buffalo milk quantified by other methods used values (Fat by the Gerber method; Acidity by the Dornic method; Protein by the Kjeldahl method). Milk FA composition was measured in individual samples from the three days of each period according to guidelines of Bulletin of International Dairy Federation $\mathrm{N}^{\circ}$ 265/1991 ("Determination of free fatty acids in milk and milk products" ISO 15884-IDF 182: Milk fat, preparation of fatty acid methyl esters).

\section{STATISTICAL ANALYSES}

Data of milk production and composition and milk FA profile were analyzed using the Student T-test for paired observations. Differences between $\mathrm{L}$ and $\mathrm{H}$ oil doses were stated using the Student t-test for independent observations $(n=7)$. Differences were considered significant with $\mathrm{P}<0.05$ unless otherwise stated. Values are presented as means followed by standard deviation.

\section{RESULTS}

Oil content for linoleic (53.61 and $15.90 \%)$ and linolenic $(0.36$ and $50.39 \%)$ FA presented normal values for soybean and linseed oils respectively. At the start of the experiment, milk yield (g/animal/day) averaged $1776( \pm 522)$ and 1662 ( \pm 291$)$ for $\mathrm{L}$ and $\mathrm{H}$ respectively (Table 1) without differences between treatment groups $(\mathrm{P}<0.622)$. At the end of the trial milk yield averaged 4590 and $4847 \mathrm{~g} / \mathrm{animal} /$ day in $\mathrm{L}$ and $\mathrm{H}$ (Table 1) without differences between oil doses $(\mathrm{P}<0.543)$.

Compared to the basal diet, milk fat content decreased in $\mathrm{L}$ and $\mathrm{H}$ whereas milk protein content increased after oil supplementation. Concentrations of de novo (4:0 a 15:1) and short chain FA (4:0 to 10:0) were reduced only in the $\mathrm{H}$ treatment (Table 2). Milk concentration of 12:0 was not affected, but the concentration of 14:0 decreased $(-24 \%, \mathrm{P}<0.007)$ only in $\mathrm{H}$ (Table 2). Concentrations of 16:0 were reduced $(\mathrm{P}<0.001)$ in both the $\mathrm{L}$ and $\mathrm{H}$ treatments (Table 2) without differences between the two doses (Table 2). The hypercholesterolemic fraction of milk fat $(12: 0$ to $16: 0)$ was reduced $(\mathrm{P}<0.001)$ in both treatments but the resulting decrease was higher $(\mathrm{P}<0.052)$ in $\mathrm{H}(-8.09 \mathrm{~g} / 100 \mathrm{~g}$ FA) compared to $\mathrm{L}(-4.72 \mathrm{~g} / 100 \mathrm{~g}$ FA). The atherogenic index of milk was reduced and was lower in $\mathrm{H}$ compared to $\mathrm{L}(\mathrm{P}<0.056)$. The concentration of VA increased $(\mathrm{P}<0.001)$ in $\mathrm{L}$ and $\mathrm{H}$ and had a higher result $(\mathrm{P}<0.001)$ in $\mathrm{H}$ (16.77g/100g FA) than in $\mathrm{L}(13.24 \mathrm{~g} / 100 \mathrm{~g}$ FA). Basal RA sharply increased in $\mathrm{L}(+127 \%)$ and $\mathrm{H}$ 
$(+187 \%)$ without differences between treatments $(\mathrm{P}<0.195)$. The basal RA/VA ratio did not change after oil supplementation. Basal concentrations of trans-10 18:1 were low and increased by the oil-blend without differences between treatments. Basal concentrations of elaidic (trans-9 18:1) acid in milk increased after oil supplementation without differences between $\mathrm{L}$ and $\mathrm{H}$. The basal $\mathrm{n}-6 / \mathrm{n}-3$ ratio was slightly increased after oil supplementation with lower results in $\mathrm{L}$ compared to $\mathrm{H}$ doses.

Table 1. Milk yield and composition in lactation buffaloes before (Basal) and 23 days after (Final) supplementation with a blend (70:30, wt:wt) of soybean and linseed oils at a low (L, 276g/d) and a high $(\mathrm{H}, 572 \mathrm{~g} / \mathrm{d})$ dose.

\begin{tabular}{lccc}
\hline & \multicolumn{2}{c}{ Basal } & Final \\
\hline & Low oil supplementation $\mathbf{( 2 7 6 g / d})$ & \\
Milk yield (g/animal/day) & $1776 \mathrm{a}( \pm 522)$ & $4590 \mathrm{~b}( \pm 991)$ & 0.0001 \\
Protein $(\mathrm{g} / 100 \mathrm{~g})$ & $4.32 \mathrm{a}( \pm 0.34)$ & $7.32 \mathrm{~b}( \pm 0.60)$ & 0.0001 \\
Fat $(\mathrm{g} / 100 \mathrm{~g})$ & $7.71 \mathrm{a}( \pm 2.05)$ & $6.07 \mathrm{~b}( \pm 2.36)$ & 0.031 \\
Total solids $(\mathrm{g} / 100 \mathrm{~g})$ & $17.83 \mathrm{a}( \pm 2.22)$ & $21.89 \mathrm{~b}( \pm 2.40)$ & 0.0001
\end{tabular}

\begin{tabular}{lccc}
\hline & High oil supplementation $(\mathbf{5 7 2} \mathbf{g} / \boldsymbol{d})$ & \\
Milk yield $(\mathrm{g} / \mathrm{animal} / \mathrm{day})$ & $1662 \mathrm{a}( \pm 291)$ & $4847 \mathrm{~b}( \pm 447)$ & 0.0001 \\
Protein $(\mathrm{g} / 100 \mathrm{~g})$ & $4.43 \mathrm{a}( \pm 0.69)$ & $6.84 \mathrm{~b}( \pm 0.49)$ & 0.0001 \\
Fat $(\mathrm{g} / 100 \mathrm{~g})$ & $7.43 \mathrm{a}( \pm 0.99)$ & $4.94 \mathrm{~b}( \pm 1.12)$ & 0.0031 \\
Total solids $(\mathrm{g} / 100 \mathrm{~g})$ & $17.40 \mathrm{a}( \pm 1.59)$ & $20.62 \mathrm{~b}( \pm 1.13)$ & 0.0011 \\
\hline
\end{tabular}

${ }^{(1)} \mathrm{a}, \mathrm{b}$ Student T-test for paired observations. Differences between L and $\mathrm{H}$ oil doses were not significant (Student Ttest for independent observations, $\mathrm{n}=7$ ).

\section{DISCUSSION}

The increase in basal milk production after oil supplementation was probably explained by a gradual adaptation of animals to milking and also by the use of oxytocin to promote the release of milk. No effect of lipid dose on milk production was observed. Supplementation with PUFA-rich oils did not affect milk yield in non- grazing (Gagliostro and Chilliard, 1992) or in grazing experiments (Schroeder et al., 2004) with dairy cows. Basal content of total solids in milk (17.6\%) was in the normal range (17\% to $18.1 \%)$ reported by Oliveira et al. (2009) using confined buffaloes and Ahmad et al. (2013) for their review on general composition of buffalo milk. After oil feeding this parameter increased up to $21.89 \mathrm{~g} / 100 \mathrm{~g}$ probably as the consequence of the higher milk protein content after the intake of oil. The increase in total solids makes this milk ideal for processing into dairy products and may also contribute to significant energy savings in manufacturing the milk. Before oil feeding milk protein content was in the normal range (4.0 to $5.0 \%$ ) reported by Oliveira et al. (2009) and Ahmad et al. (2013). After oil intake, this parameter showed a noticeable increase reaching values as high as 6.84 and $7.32 \%$. Milk protein content was not affected when confined buffaloes were supplemented with different lipid sources (Oliveira et al., 2009). As synthesis of milk protein can be limited by energy availability some additional energy absorbed after oil intake could improve energy status of the buffaloes and enhance milk protein synthesis explaining in part the increase in milk protein content. In fact, a possible dilution effect of milk protein was not observed as milk production increased. Average basal values of fat $(7.43-7.71 \%$, Table 1$)$ were below the normal concentration $(8.3 \%)$ reported by Varrichio et al. (2007). The lower milk fat content after oil supplementation ( $\mathrm{L}=$ $1.64 \mathrm{~g} / 100 \mathrm{~g}$ and $\mathrm{H}=-2.49 \mathrm{~g} / 100 \mathrm{~g}$, Table 1 ) could be explained in part by a dilution effect as milk yield increased (Table 1) and was not reported for confined buffaloes supplemented with soybean oil at a rate of $2.21 \%$ of total DM intake (Oliveira et al., 2009). Fat content in milk (8.66 to $9.40 \mathrm{~g} / 100 \mathrm{~g})$ and in mozzarella cheese $(21.05$ to $25.27 \mathrm{~g} / 100 \mathrm{~g})$ were increased $(\mathrm{P}<0.05)$ by supplementation with soybean oil (Oliveira et al., 2009). In our trial the lower milk fat concentration could also be explained by the increase (and ulterior transfer to the udder) of some trans-FA formed by ruminal biohydrogenation which have antilipogenic properties (Shingfield et al., 2010). The uptake of trans-10, cis-12 CLA, trans-9, cis-11 CLA, 
cis-10, trans-12 CLA and trans-8, cis-10 CLA reduce the activity and/or expression of genes that encode important enzymes involved in uptake, synthesis and desaturation of FA in the mammary gland (Chilliard et al., 2000,
Shingfield et al., 2010). The decrease in milk fat content at both oil doses was mainly explained by a reduction in the hypercholesterolemic FA of milk fat improving the health benefits of the product.

Table 2. Milk fatty acid composition in lactation buffaloes before (Basal) and after (Final) supplementation with a blend (70:30 wt/wt) of soybean and linseed oils at low (LO, 276g/d) and a high (HO, 572g/d) doses

\begin{tabular}{|c|c|c|c|c|c|c|c|}
\hline & \multicolumn{3}{|c|}{$\mathrm{LO}$} & \multicolumn{2}{|c|}{$\mathrm{HO}$} & \multicolumn{2}{|c|}{$\begin{array}{c}\text { Final LO vs } \\
\text { Final HO } \\
\end{array}$} \\
\hline & Basal & Final & $P<^{(1)}$ & Basal & Final & $P<(1)$ & $P<^{(2)}$ \\
\hline $4: 0$ & $2.44( \pm 0.31)$ & $2.69( \pm 0.48)$ & 0.125 & $2.50( \pm 0.28)$ & $2.23( \pm 0.21)$ & 0.053 & 0.036 \\
\hline 6:0 & $0.70( \pm 0.14)$ & $0.79( \pm 0.27)$ & 0.311 & $0.71( \pm 0.10)$ & $0.61( \pm 0.13)$ & 0.084 & 0.130 \\
\hline 8:0 & $0.25( \pm 0.06)$ & $0.29( \pm 0.11)$ & 0.272 & $0.24( \pm 0.05)$ & $0.21( \pm .06)$ & 0.193 & 0.117 \\
\hline 10:0 & $0.46( \pm 0.10)$ & $0.52( \pm 0.19)$ & 0.252 & $0.45( \pm 0.09)$ & $0.40( \pm .11)$ & 0.332 & 0.180 \\
\hline 12:0 & $0.79( \pm 0.13)$ & $0.86( \pm 0.20)$ & 0.215 & $0.80( \pm 0.11)$ & $0.73( \pm 0.13)$ & 0.111 & 0.169 \\
\hline 14:0 & $4.88( \pm 0.70)$ & $4.85( \pm 0.98)$ & 0.880 & $5.29( \pm 0.77)$ & $4.03( \pm 0.41)$ & 0.007 & 0.067 \\
\hline Iso $15: 0$ & $0.73( \pm 0.08)$ & $0.62( \pm 0.13)$ & 0.170 & $0.75( \pm 0.14)$ & $0.42( \pm 0.13)$ & 0.002 & 0.016 \\
\hline $15: 0$ & $1.26( \pm 0.12)$ & $0.90( \pm 0.06)$ & 0.001 & $1.35( \pm 0.10)$ & $0.83( \pm 0.06)$ & 0.001 & 0.028 \\
\hline $15: 1$ & $0.40( \pm 0.05)$ & $0.24( \pm 0.02)$ & 0.001 & $0.39( \pm 0.06)$ & $0.17( \pm 0.03)$ & 0.001 & 0.001 \\
\hline $16: 0$ & $24.49( \pm 0.67)$ & $19.75( \pm 0.77)$ & 0.001 & $25.92( \pm 2.14)$ & $19.17( \pm 0.89)$ & 0.001 & 0.211 \\
\hline $12: 0+14: 0+16: 0$ & $30.17( \pm 1.24)$ & $25.45 \pm 1.82)$ & 0.001 & $32.02( \pm 0.76)$ & $23.93( \pm 0.45)$ & 0.001 & 0.052 \\
\hline A. Index ${ }^{(2)}$ & $1.09( \pm 0.13)$ & $0.83( \pm 0.15)$ & 0.001 & $1.24( \pm 0.18)$ & $0.71( \pm 0.03)$ & 0.001 & 0.056 \\
\hline $16: 1$ & $1.22( \pm 0.13)$ & $0.87( \pm 0.86)$ & 0.012 & $1.23( \pm 0.27)$ & $0.68( \pm 0.15)$ & 0.002 & 0.042 \\
\hline $17: 0$ & $1.19( \pm 0.20)$ & $0.66( \pm 0.05)$ & 0.001 & $1.13( \pm 0.12)$ & $0.58( \pm 0.04)$ & 0.001 & 0.008 \\
\hline $17: 1$ & $0.41( \pm 0.08)$ & $0.18( \pm 0.02)$ & 0.001 & $0.36( \pm 0.05)$ & $0.14( \pm 0.03)$ & 0.001 & 0.005 \\
\hline 18:0 & $19.35( \pm .80)$ & $18.16( \pm .52)$ & 0.297 & $19.80( \pm 2.97)$ & $19.09( \pm 0.31)$ & 0.513 & 0.391 \\
\hline trans-8 18:1 & $0.60( \pm 0.13)$ & $1.08( \pm 0.14)$ & 0.002 & $0.61( \pm 0.08)$ & $1.09( \pm 0.08)$ & 0.001 & 0.956 \\
\hline trans-9 18:1 & $0.40( \pm 0.07)$ & $0.74( \pm 0.07)$ & 0.001 & $0.38( \pm 0.02)$ & $0.75( \pm 0.07)$ & 0.001 & 0.773 \\
\hline trans-10 18:1 & $0.44( \pm 0.20)$ & $0.91( \pm 0.28)$ & 0.034 & $0.42( \pm 0.06)$ & $0.85( \pm 0.22)$ & 0.003 & 0.698 \\
\hline trans-11 18:1 (VA) & $5.70( \pm 0.37)$ & $13.24 \pm 1.66)$ & 0.001 & $5.25( \pm 0.62)$ & $16.77( \pm 1.36)$ & 0.001 & 0.001 \\
\hline cis-9 18:1 & $28.90( \pm 0.55)$ & $25.06 \pm 2.41)$ & 0.020 & $27.17( \pm 2.55)$ & $23.09( \pm 2.38)$ & 0.001 & 0.148 \\
\hline cis-11 18:1 & $0.88( \pm 0.07)$ & $0.94( \pm 0.07)$ & 0.235 & $0.90( \pm 0.05)$ & $1.01( \pm 0.10)$ & 0.050 & 0.158 \\
\hline trans-9,trans-12 18:2 & $0.08( \pm 0.01)$ & $0.16( \pm 0.02)$ & 0.001 & $0.08( \pm 0.01)$ & $0.20( \pm 0.04)$ & 0.001 & 0.035 \\
\hline cis-9, cis-12 18:2 & $1.73( \pm 0.17)$ & $1.74( \pm 0.10)$ & 0.819 & $1.78( \pm 0.19)$ & $1.80( \pm 0.27)$ & 0.877 & 0.668 \\
\hline $\mathrm{C} 18: 3 c 9, c 12, c 15$ & $0.64( \pm 0.13)$ & $0.49( \pm 0.06)$ & 0.043 & $0.60( \pm 0.13)$ & $0.42( \pm 0.09)$ & 0.002 & 0.143 \\
\hline cis-9,trans-11 18:2 (RA) & $1.80( \pm 0.27)$ & $4.09( \pm 0.59)$ & 0.001 & $1.60( \pm 0.31)$ & $4.61( \pm 0.83)$ & 0.001 & 0.195 \\
\hline De novo FA (4:0-15:1) & $12.00( \pm 1.30)$ & $11.84( \pm .31)$ & 0.792 & $12.59( \pm 1.35)$ & $9.70( \pm 0.99)$ & 0.004 & 0.044 \\
\hline Preformed FA (>17:0) & $62.27( \pm 1.58)$ & $67.54( \pm 3.02)$ & 0.001 & $60.24( \pm 3.39)$ & $70.46( \pm 0.48)$ & 0.001 & 0.026 \\
\hline $\mathrm{RA} / \mathrm{VA}$ ratio & $0.32( \pm 0.04)$ & $0.31( \pm 0.05)$ & 0.919 & $0.31( \pm 0.06)$ & $0.28( \pm 0.06)$ & 0.333 & 0.278 \\
\hline Short chain FA (4:0 to 10:0) & $3.85( \pm 0.59)$ & $4.30( \pm 1.03)$ & 0.159 & $3.90( \pm 0.35)$ & $3.45( \pm 0.39)$ & 0.086 & 0.063 \\
\hline Long chain FA (18:0 to $22: 6$ ) & $60.67( \pm 0.38)$ & $66.70( \pm .00)$ & 0.001 & $58.75( \pm 3.29)$ & $69.75( \pm 0.52)$ & 0.001 & 0.021 \\
\hline$n-6 / n-3$ & $2.46( \pm 0.41)$ & $3.32( \pm 0.25)$ & 0.004 & $2.71( \pm 0.31)$ & $4.03( \pm 0.46)$ & 0.001 & 0.004 \\
\hline
\end{tabular}

Concentrations of butyric and linolenic acids resulted in values close to those reviewed by Ahmad et al. (2013), while those of caproic, caprylic, capric, lauric, myristic and palmitic acids were lower and stearic, trans-10 octadecenoic, vaccenic, oleic (cis-9 18:1), linoleic (cis-9, cis-12 18:2) and rumenic acids had higher results. Average concentrations of stearic $(107 \%)$, oleic $(+42 \%)$, vaccenic $(+185 \%)$, rumenic $(+100 \%)$, total trans $18: 1+$ rumenic $(+98 \%)$ and the $n-6 / n-3$ ratio $(89 \%)$ had higher results, whereas those of lauric $(-66 \%)$, myristic $(-59 \%)$ and palmitic $(-32 \%)$ were lower than those reviewed by Ahmad et al. (2013).

Regarding saturated FA, Soliman et al. (1979) observed an average total content of $71.7 \%$ in Egyptian buffalo milk fat, a value resulted near 
to that reported by Oliveira et al., (2009) in their confined experiment $(69.8 \%)$ but higher than the observed in the milk fat (56-59\%) for the grazing buffaloes used in the present experiment. Polidori et al. (1997) also reported that buffalo milk contains about $67 \%$ of saturated FA, while Van Nieuwenhove et al. (2004) reported values of $59 \%$ for long-chain saturated FA in animals fed on natural pastures. After oil intake total SFA in milk decreased up to $50.09 \%$ in L and $48.3 \%$ in $\mathrm{H}$ doses with a UFA/SFA ratio near to 1 .

In Oliveira et al. (2009) feeding soybean oil resulted in an approximate $10 \%$ decrease in SFA relative to the control treatment or when oil was supplied as soybean grain. In Oliveira et al. (2009), baseline for the hypercholesterolemic FA $(45.8 \mathrm{~g} / 100 \mathrm{~g})$ was higher than the average observed in our grazing experiment (30.15 to $32.02 \mathrm{~g} / 100 \mathrm{~g}$, Table 2). Beyond type of diet, milk concentration of 12:0 and 14:0 was also associated with higher body condition of buffaloes (Ahmad et al., 2013) and the difference with Oliveira's data may also be explained by the moderate body condition of our grazing animals. In the study by Fernandes et al. (2007) the hypercholesterolemic FA varied from 32.48 to $42.9 \%$. When considering only the SFA able to raise LDL blood levels (lauric, mirystic and palmitic) feeding the oil-blend has reduced their concentrations with emphasis on $\mathrm{H}$ (23.93g/100g) compared to L $(25.45 \mathrm{~g} / 100 \mathrm{~g})$ doses (Table 2). After supplementation with the oil-blend, the concentration of human atherogenic FA was lower than the values of $43 \mathrm{~g} / 100 \mathrm{~g}$ reported by Oliveira et al. (2009). Supplementation with the high dose of oil-blend was the most effective way to reduce the total concentration of hypercholesterolemic FA and the atherogenic index of milk fat (Table 2).

Average baseline records for 18:0 (19.57g/100g) were well above the range (7.86-13.44) reported by Fernandes et al. (2007) for Brazilian buffaloes. Supplementary 18:2 did not enhance the concentration of 18:0 in milk fat (Table 2) suggesting that increased biohydrogenation of 18:2 (and also VA) in the rumen probably did not occur. Feeding soybean oil but not soybean grain reduced the concentration of 18:0 in milk fat of lactating buffaloes (Oliveira et al., 2009).

In our experiment, average basal content of oleic acid $(28.04 \mathrm{~g} / 100 \mathrm{~g})$ was above the range (20.6 to
$25.1 \mathrm{~g} / 100 \mathrm{~g})$ reported by Fernandes et al. (2007) for Brazilian buffaloes resulting also well above than observed in confined buffaloes $(20.35 \mathrm{~g} / 100 \mathrm{~g})$ fed TMR diets (Oliveira et al., 2009) but near the values of $29.47 \mathrm{~g} / 100 \mathrm{~g}$ reported by Qurshi et al. (2010). In confined diets (Oliveira et al., 2009), feeding soybean oil (but not soybean grain) increased oleic acid in milk up to $25 \mathrm{~g} / 100 \mathrm{~g}$, whereas in our experiment this FA decreased in both $\mathrm{L}$ and $\mathrm{H}$ oil doses (Table 2). As oils contained about $19 \%$ of oleic acid (Table 1) a high rumen hydrogenation of this FA seems probable. Some inhibition by trans isomers of delta-9 desaturase enzyme in the mammary gland (Shingfield et al., 2010) may also explain the observed reduction in oleic acid. In our trial, average basal concentration of RA $(1.70 \mathrm{~g} / 100 \mathrm{~g}$ FA) was in the upper range limit $(1.02-1.77 \mathrm{~g} / 100 \mathrm{~g})$ reported by Fernandes et al. (2007) for buffaloes on commercial farms in Brazil although the average values observed were about $1.1 \mathrm{~g} / 100 \mathrm{~g}$ in four of the five tested farms.

Baseline RA (Table 2) was 1.74 times higher than values of $0.98 \mathrm{~g} / 100 \mathrm{~g}$ FA reported by Oliveira et al. (2009). The relative increase in milk RA after oil supplementation $(127 \%$ and $188 \%$ ) was higher than the obtained by Oliveira et al. (2009) in buffaloes supplemented with soybean grain $(+13.3 \%)$ or soybean oil $(+102 \%)$. The average RA concentration obtained after oil supplementation $(4.35 \mathrm{~g} / 100 \mathrm{~g}$, Table 2) was higher than the total CLA concentration of $1.95 \mathrm{~g} / 100 \mathrm{~g}$ when $2 \%$ of mustard oil was added to the diet of Murrah buffaloes (Kathirvelan and Tyagi, 2009). The relative increase in $\mathrm{H}$ oil treatment $(188 \%$, Table 2$)$ was near to that informed $(185 \%)$ by Kathirvelan and Tyagi (2009). In their experiment the average total CLA contents (g/100g milk fat) was $0.684,1.212$ and 1.95 when animals were fed groundnut cakebased concentrate, mustard cake-based concentrate and $2 \%$ of mustard oil respectively.

Baseline of total trans FA in milk $(6.90 \mathrm{~g} / 100 \mathrm{~g}$, Table 2) was sharply increased $(17.72 \mathrm{~g} / 100 \mathrm{~g})$ after oil supplementation. Intake of trans fatty acids has been associated with an increased risk of human cardiovascular disease but results from epidemiological studies have indicated that the intake of rumenic trans FA is innocuous or even protects against cardiovascular disease (Jakobsen et al., 2008; Bendsen et al., 2011). In the 
industrially produced hydrogenated fats, the elaidic acid and trans-10 18:1 are the prevailing trans-FA while VA is the major trans-FA in milk. In our trial, elaidic acid represented only $5.65 \%$ of total trans and decreased to $4.24 \%$ after oil supplementation whereas trans-10 18:1 represented about $6.23 \%$ and $5.03 \%$, respectively.

Vaccenic acid represented $79.3 \%$ and $84.5 \%$ of total trans in basal or after oil supplementation respectively (Table 2). At about $2.21 \%$ of estimated total DMI the oil mix supplied apparently exceeded the desaturation capacity of the mammary gland to convert VA to RA because in doubling the dose an increase in the concentration of VA was obtained without further increases in the content of RA. The presence of VA in dairy products may also have beneficial health properties through its direct anticarcinogenic properties (Awad et al., 1995) or mediated through its endogenous conversion to RA by delta- 9 desaturases in human tissues (Parodi, 2003). The conversion of VA to RA has been shown to prevent chemically induced carcinogenesis in rodents (Banni et al., 2001). In spite of the increased availability of linoleic and linolenic acids after oil supplementation its incorporation to milk fat was negligible suggesting a moderate efficiency in the transfer of these FA to milk and a high rate of rumen biohydrogenation in buffaloes.

\section{CONCLUSIONS}

In the extensive production conditions of the present work based on natural grassland diets, buffalo milk represented a good source of RA. Supplementation with a mixture (70:30) of soy and linseed oils at $2.21 \%$ of estimated DM intake reduced milk fat concentration, increased milk protein and total solid contents and induced profound changes in the milk FA profile. The concentration of the potentially human atherogenic FA and the atherogenic index of milk were attenuated while the RA concentration was sharply increased. This fact should contribute to alleviate the dieticians' criticism against dairy products for their ability to raise LDL cholesterol and to improve the health quality of buffalo milk and its image as perceived by the consumer.

\section{ACKNOWLEDGEMENTS}

The authors thank Architect Tomas Terranova and the staff of the Farm Nuestra Señora de Itatí for providing the facilities and animals for the realization of this work. The same was partially supported with funding from the project FS01/10 FONARSEC Iniciativa Lácteos Alto CLA (Ministry of Science, Technology and Innovation (MinCyT). Argentina), the National Institute of Industrial Technology (INTI), the National Institute of Agricultural Technology (INTA), the National University of the Northeast (UNNE), Faculty of Veterinary Science and the farm Nuestra Señora de Itatí- Corrientes-Argentina. To Dr. Yves Chilliard (INRA, Fr) and Marco Sundfeld Gama (EMBRAPA, Br) for their valuable suggestions for the preparation of the manuscript.

\section{REFERENCES}

AHMAD, S.; ANJUM, F.M.; HUMA, N. et al. Composition and physicochemical characteristics of buffalo milk with particular emphasis on lipids proteins, minerals, enzymes and vitamins. The $J$. of Anim. and Plant Sci., v.23, p.62-74, 2013.

AWAD, A.B.; HERMANN, T.; FINK, C.S.; HORVATH, P.J. 18:1 n7 Fatty acids inhibit growth and decreased inositol phosphate release in HT-29 cells compared to n-9 fatty acids. Cancer Lett, v.91, p.55-61, 1995.

JAKOBSEN, L.; SANDVANG, D.; HANSEN, L.H.; $e t$ $a l$. Characterisation, dissemination and persistence of gentamicin resistant Escherichia coli from a Danish university hospital to the waste water environment. Environ Int 34, 108-115, 2008.

BANNI, S.; ANGIONI, E.; MURRU, E. et al. Vaccenic acid feeding increases tissue levels of conjugated linoleic acid and suppreses development of premalignant lesions in at mammary gland. Nutr. Cancer, v.41, p.91-97, 2001.

BENDSEN N.T; CHRISTENSEN R, BARTELS E.M.; ASTRUP A. Consumption of industrial and ruminant trans fatty acids and risk of coronary heart disease: a systematic review and meta-analysis of cohort studies. European Journal of Clinical Nutrition, 65, 773-783, 2011.

CHILLIARD Y.; FERLAY A.; MANSBRIDGE R.M.; DOREAU M. Ruminant milk fat plasticity: nutritional control of saturated, polyunsaturated, trans and conjugated fatty acids. Ann. Zootech., v.49, p.181-205, 2000. 
CHILLIARD, Y.; FERLAY, A. Dietary lipids and forages interactions on cows and goat milk acid composition and sensory properties. Reprod. Nutr. Dev., v.44, p.467-492, 2004.

CHILLIARD Y.; GLASSER F.; FERLAY A. et al. Diet, rumen biohydrogenation, cow and goat milk fat nutritional quality: a review. Europ. J. of Lipid Sci. and Technol., v.109, p.828-855, 2007.

FERNANDES, S.A.A.; MATTOS, W.R.S.; MATARAZZO, S.V. et al. Total fatty acids in Murrah Buffaloes milk on commercial farms in Brazil. Ital. J. Anim. Sci., v.6, p.1063-1066, 2007.

GAGLIOSTRO, G.A.; CHILliARD, Y. Revisión bibliográfica. Utilización de lípidos protegidos en nutrición de vacas lecheras. I. Efecto sobre la producción y la composición de la leche y sobre la ingestión de materia seca y energía. Rev. Arg. Prod. Anim., v.12, p.1-15, 1992.

KATHIRVELAN， C.; TYAGI，A.K. Conjugated linoleic acid content of milk from buffaloes fed a mustard oil-based diet. International J. Dairy Technol., v.62, p.141-292, 2009.

MÉNARD, O.; AHMAD, S.; ROUSSEAU, F. et al. Buffalo vs. cow milk fat globules: Size distribution, zeta-potential, compositions in total fatty acids and in polar lipids from he milk fat globule membrane. Food Chem., v.120, p.544-551, 2010.

OLIVEIRA, R.L.; LADEIRA, M.M.; BARBOSA, M.A.A.F. et.al. Composição química perfil de ácidos graxos do leite e muçarela de búfalas alimentadas com diferentes fontes de lipídeos. Arq. Bras. Med. Vet. Zootec., v.61, p.736-744, 2009.

PARODI P.W. Conjugated linoleic acid and other anticarcinogenic agents of bovine milk fat. J. Dairy Sci., v.82, p.1339-1349, 1999.

PARODI P.W. Conjugated linoleic acid in food. In: SÉBÉDIO, J.L.; CHRISTIE, W.W.; ADLOFF, R. (Eds.). Advances in Conjugated Linoleic Acid in Food. Volume 2. AOCS Press, Champaign, Illinois. 2003. p.1-122.

PATIÑO, E.M.; JUDIS, M.A.; GUANZIROLI STEFANI, C. et al. Conjugated Linoleic Acid and Omega 6 and 3 in Buffalo (Bubalus bubalis) Milk in Corrientes, Argentina. Rev. Vet., v.21 (Suppl. 1), p.244-248, 2010
POLIDORI, F.; SGOIFO ROSSI, C.A.; SENATORIE, E.M.; et al. Effect of recombinant bovine somatotropin and calcium salts of long-chain fatty acids on milk from Italian buffalo. J Dairy Sci 80: 2137-2142, 1997.

QURSHI M.S.; MUSHTAQ, A.; KHAN, S. et al. Variation in milk fatty acid composition with body condition in dairy buffaloes (Bubalusbubalis). AsianAust J. Animal Sci., v.23, p.340-346, 2010.

REGO, O.A; ROSA, H.J.D.; PORTUGAL, P.V. et $a l$. The effects of supplementation with sunflower and soybeans oils on the fatty acid profile of milk fat from grazing dairy cows. Anim. Res., v.54, p.17-24, 2005.

SHINGFIELD, KJ.; BERNARD, L.; LEROUX, C.; CHILLIARD, Y. Role of trans fatty acids in the nutritional regulation of mammary lipogenesis in ruminants. Animal, v. 4, p. 1140-1166, 2010.

SCHROEDER, G.F.; GAGLIOSTRO, G.A.; BARGO, F. et al. Effects of fat suplementation on milk production and composition by dairy cows on pasture: a review. Livest. Prod. Sci., v.86, p.1-18, 2004.

SOLIMAN, H.S.; ØRSKOV, E.R.; ATKINSON, T.; AND SMART, R.I. Utilization of partially hydrolysed starch in milk replacers by newborn lambs. J. Agric. Sci., v.92, p.343-349, 1979.

STANTON, C.; MURPHY, J.; MCGRATH, E.; DEVERY, R. Animal feeding strategies for conjugates linoleic acid enrichment of milk. In: SÉBÉDIO, J.L; CHRISTIE, W.W.; ADLOFF, R. (Eds.). Advances in Conjugated Linoleic Acid in Food. Volume 2. AOCS Press, Champaign, Illinois, p.123145. 2003

ULBRITCH, T.L.; SOUTHGATE, D.A.T. Coronary heart disease: seven dietary factors. Lancet., v.338, p.985-992, 1991.

VAN NIEUWENHOVE, C.; GONZALEZ, S.; PEREZ-CHAIA, A.; RUIZHOLGADO, A.P. Conjugated linoleic acid in buffalo (Bubalus bubalis) milk from Argentina. Milchwissenschaft 59: 9-10. 2004

VARRICHIO, M. L.; DI FRANCIA, A.; MASUCCI, F. et al. Fatty acid composition of Mediterranean buffalo milk fat. Italian J. Animal Sci., v.6, p.9-511, 2007. 